\title{
INITIAL DEVELOPMENT OF AÇAÍ PLANTS UNDER SHADE GRADATION ${ }^{1}$
}

\author{
ELEANDRO CANDIDO DAPONT ${ }^{2}$, JOSUÉ BISPO DA SILVA ${ }^{3}$, CHARLINE ZARATIN ALVES $^{4}$
}

ABSTRACT - In order to evaluate the effect of different levels of shading on açai (Euterpe oleracea Mart.) plants development, an experiment was conducted at the Viveiro da Floresta, Rio Branco, AC. The experiment was arranged in a completely randomized design with six treatments and four replications of 25 plants, set as full sunlight and $18 \%, 35 \%, 50 \%, 70 \%$, and $80 \%$ shading. The evaluation occurred 125 days after transplantation and the variables were stem diameter, root length, length of the aerial part, total length, dry matter of root, dry matter of aerial part, and total dry matter. With exception of root length, there was significant difference between treatments for all variables. The production of açai plants should be performed using $40 \%$ shading.

Index terms: Euterpe oleracea, plant propagation, luminosity, Arecaceae.

\section{DESENVOLVIMENTO INICIAL DE PLANTAS DE AÇAÍ SOB GRADUAÇÕES DE SOMBREAMENTO}

RESUMO - Com o objetivo de avaliar o efeito de diferentes níveis de sombreamento no desenvolvimento de plantas de açaí (Euterpe oleracea Mart.) foi instalado um experimento no Viveiro da Floresta em Rio Branco, AC. O arranjo experimental foi o inteiramente ao acaso com seis tratamentos e quatro repetições de 25 plântulas, definidos como a pleno sol e os sombreados em 18\%,35\%, 50\%, 70\% e 80\%. A avaliação ocorreu 125 dias após o transplantio e as variáveis analisadas foram o diâmetro do colo, comprimento da raiz, parte aérea e total, massa seca da raiz, parte aérea e total. Com exceção do comprimento da raiz, houve diferença significativa entre os tratamentos para todas as variáveis. A produção de plantas de açaí deve ser feita utilizando $40 \%$ de sombreamento.

Termos para indexação: Euterpe oleracea, produção de mudas, luminosidade, Arecaceae.

1(Trabalho 178-15).Recebido em: 15-07-2015. Aceito para publicação em: 16-09-2015.

${ }^{2}$ Eng. Agr. Mestre em Agronomia, Universidade Federal do Acre, Campus Rio Branco, AC. E-mail: candidodapont@gmail.com

${ }^{3}$ Eng. Agr. Dr. Professor, Universidade Federal do Acre, Campus Rio Branco, AC. E-mail: josuebispo@bol.com.br

${ }^{4}$ Eng. Agr. Dra. Professora, Universidade Federal do Mato Grosso do Sul, Campus Chapadão do Sul, MS. E-mail: charline.alves@ufms.br 


\section{INTRODUCTION}

The adaptation of plants is a long term process involving various generations. In unfavorable growth situations, they use different resources to achieve the minimal conditions for development and reproduction.

Palm trees adapts to different environments such as floodplain, igapó, and solid ground due to its ability to allocate resources for leaves and roots. The efficiency of leaves for light interception, the ability to convert this energy into carbohydrates, as well as its transport and metabolism in the different parts within the tree are factors that influence the growth and survival of palm trees developing in adversity (SCARIOT, 2001).

The light availability affects the development of plants due to the amount of light energy intercepted by the leaves. The satisfactory growth of some species in environments with different light intensities might be attributed to the capacity to quickly adjust its physiological behavior in order to maximize the input of resources in such environments.

Species like catingueira (Poincianella pyramidalis (Tul.) L. P. Queiroz - Caesalpinioideae) developed better with $30 \%$ and $50 \%$ of shading, compared to full sunlight (ANTUNES et al., 2014). There are differences in the light requirements even within the same species. For instance, in the studies of Gondin et al. (2015) the aerial parts of paricá plants (Schizolobium amazonicum Huber ex. Ducke - Caesalpinioideae) showed lower development with $50 \%$ of shading, compared to full sunlight, whereas Matos et al. (2009) observed a more expressive growth of aerial parts with $75 \%$ of shading.

Young plants of juçara palm (Euterpe edulis Martius - Arecaceae) showed greater survival index in canopy gap environments (53\%), with greater light availability, than in understory environment (20\%) (RIBEIRO et al., 2011), as well as carnauba palm (Copernicia prunifera (Miller) H. E. Moore Arecaceae) that developed better when growing at full sunlight when compared to plants growing under $50 \%$ of shading (REIS et al., 2011). Few studies were performed with açaizeiro (Euterpe oleraceae Mart. - Arecaceae) if compared to other crops, especially regarding the problems and requirements associated with the production of plants in the initial stages. In practice, it has been observed significant losses in the nursery due to several factors, such as the level of light incidence.

Therefore, due to the need of scientific studies to provide appropriate techniques to properly form the plants, the aim of this study was to evaluate the initial development of açai plants grown under different levels of shading, in Rio Branco, Acre.

\section{MATERIAL AND METHODS}

The experiment was performed in the Viveiro da Floresta, located in the AC 40 road, km 02 (67 $67^{\circ}$ 53 " W, $10^{\circ} 01$ ' 23 " $\mathrm{S}$ and altitude of $144 \mathrm{~m}$ ), in Rio Branco, AC, from November 2011 to March 2012.

An area permanently exposed to sunlight was selected inside the nursery to avoid shade interference in the experiment. Based on that, the selected bench was adapted to receive the agricultural net, made of polyethylene.

Metallic structures, in a spacing of five meters, were adapted on the bench, to support each net, forming a half-circle of $180^{\circ}$ over the bench, with the center at $1.2 \mathrm{~m}$ height above the trays; the corners were closed with the same net in such a way that all luminosity suffered the same interference before reaching the plants. Five of these structures were built in order to obtain five shading gradations, besides the treatment at full sunlight, totaling six treatments, where the nets were purchased with the following specifications: $18,35,50,70$, and $80 \%$ of shading.

The plants of açai (Euterpe oleracea) used in the evaluation were obtained from seeds germinated in the nursery, transplanted to tubes of $120 \mathrm{~cm}^{3}$ at the toothpick stage, in November 2011. Then, they were placed on the benches in such a way that each level of shading had four replications of 25 plantlets, which were irrigated daily with a blade of $4 \mathrm{~mm}$, split in various applications throughout the day.

The experiment was arranged in a completely randomized design, and the treatments were: $\mathrm{T} 1-0 \%$ of shade (full sunlight), T2 - 18\% of shade, T3 -35 $\%$ of shade, T $4-50 \%$ of shade, T $5-70 \%$ of shade, and T6 - $80 \%$ of shade. The experiment ended in 13 March, 2012, when samples of 10 plantlets per replication were randomly collected. From these samples, the aerial part was separated from the roots using scissors, followed by the measurement of stem diameter (SD), root length (RL), and length of the aerial part (LAP), where the data were expressed in millimeters. The evaluations were performed after the drying of the samples, in order to obtain the dry matter of root (DMR), dry matter of aerial part (DMAP) and total dry matter (TDM), expressed in grams.

The process of drying was performed in a microwave, according to Souza et al. (2002). Previously to the statistical analysis, the assumptions of normality of residuals and homogeneity of 
variance were checked, using Shapiro-Wilk and Bartlett test, respectively.

In the regression analysis, when the $\mathrm{F}$ test indicated the existence of significance at $5 \%$ of probability for more than one regression, it was defined the equation of greater significant degree up to the second degree.

\section{RESULTS AND DISCUSSION}

The different levels of shading significantly influenced the variables analyzed, except root length. This can be explained by the growth limitation offered by the tubes which restricted root growth to its length $(12 \mathrm{~cm})$, occurring aerial pruning after that limit.

Although root length did not statistically differ among the levels of shading, the same did not occur with dry matter of root (Figure 1), when the greatest values were obtained with $35 \%$ of shade, indicating that the shade influenced root development, since it has relationship with the growth of the aerial part, indicating that the peak of dry matter of root can be obtained with $38 \%$ shading, which is a value very close to $35 \%$.

The behavior of the variable length of aerial part (Figure 2) indicates that the plants of açai grew more as shading levels increased, but its growth was reduced when light restriction was more intense, over $50 \%$, characterizing itself as a plant of great development capacity in different light intensities. However, the distinct light conditions produced in the canopy gaps and understory environments did not interfere in the height of E. edulis plants (RIBEIRO et al., 2011).

Considering that plant height may not be a good indicator of plant quality, due to the factors that can influence the treatments, such as the competition among plants depending on the luminosity, the greater growth in height of the shaded treatments may have occurred due to the etiolation induced by the low light intensity or because it was favored by low temperatures of the leaves, due to stomatal opening and carbon fixation by the plants (DIAS; MARENCO, 2007) (Figure 2).

The height increase of plants kept under light restriction is justified by the action of auxin, a plant hormone synthesized in young leaves and shoot apex, which is then transported to roots; light will work as a stimulant to this transport. In shading situations, auxin is laterally redistributed to the epidermis and cortical cells of the hypocotyl, causing the elongation of these tissues and then, the etiolation (MORELLI; RUBERTI, 2000). However, shading likely have controlled leaf temperature and, consequently, the water status of the plant, in order to allow an optimization of photosynthetic activity and turgescence, which are necessary to plant growth.

Plants of ipê (Tabebuia heptaphyilla (vell.) tol. - Caesalpinioideae) evaluated in full sunlight conditions, natural shade, and $50 \%$ of shade reached greater height in the latter environment (SIEBENEICHER et al., 2008), as well as of taxi branco trees (Sclerolobium paniculatum Vogel Caesalpinioideae) (FREITAS et al., 2012).

Considering the dry matter of aerial part differences were found among treatments, where the greatest value was found for the level of $35 \%$ of shading, with the maximum indicated by the equation of $42,38 \%$ with optimum adjust of the model $\left(\mathrm{R}^{2}=\right.$ 0,9114) (Figure 3).

The shading in the first months of palm trees is critical for its survival, because it reduces plant metabolism and can adjust it to adverse conditions such as soil water deficit and high luminosity (AGUIAR, 1988). In this sense, Faria et al. (2002) evaluated the behavior of several genotypes of coconut trees and concluded that, regardless the genotype, shading conditions resulted in the formation of more vigorous trees.

Analyzing the early growth of Euterpe edulis in different light regimes, Nakazono et al. (2001) described that plants developed in 20,30, 50, and $70 \%$ of light had similar development regarding dry matter, leaf area, and distribution of biomass between the root and aerial part, but differed from those grown at full sunlight, which showed less dry matter than shaded plants, agreeing with the results of the present study regarding the full sunlight treatment and disagreeing from the other degrees of shading which showed significant differences among the treatments.

Studying the development of açaizeiro of solid ground, cultivar Para, under mitigation of the solar radiation during nursery stage, Conforto and Contin (2009) reported that light treatments did not significantly change the average content of dry matter. Under $50 \%$ and $16 \%$ shading it was observed, respectively, 3.42 and $3.73 \mathrm{~g}$ for the stem, 2.42 and $2.53 \mathrm{~g}$ for the root and, 3.02 and $3.23 \mathrm{~g}$ for the leaves when the plants were 18 months old. These results do not corroborate with the present study, since until the fourth month there were differences among light treatments (Figures 1, 2, 3, 4, and 5).

In açaizeiros grown in Amapa, Conforto and Contin (2009) found $2.32 \mathrm{~g}$ for the root and $6.79 \mathrm{~g}$ for the aerial part in plants of the same age. Such values are also very close to those found by Bovi et al. (1994) for E. oleraceae grown in Campinas (SP), 
where the dry matter weight ranged from 2 to $10 \mathrm{~g}$ for the set of stem and leaves and between 0.4 and $2.4 \mathrm{~g}$ for the root. These authors compared the means of the treatments and not the point of maximum, correlating the levels of shading with plant development, such as in the present study.

Plants of E. edulis (juçara palm) growing under full sunlight reduced the accumulation of dry matter, proving to be intolerant to this light condition. This behavior was similar to that showed by plants of E. oleracea studied, which did not show positive results for the treatment at full sunlight (NAKAZONO et al., 2001).

In the research of Illenseer and Paulilo (2002) and Nakazono et al. (2001) with E. edulis in different levels of luminosity, it was observed greater growth of the caulicle in the range of irradiation from $20 \%$ to $80 \%$. In this sense, the growth data of diameter and length of the caulicle found in this study corroborate with the authors above mentioned, confirming the importance of light restriction in the initial growth of açaizeiros.

Regarding stem diameter (Figure 4), the behavior was linear, where the greater the level of shading, the lower de stem diameter of the plants. Similar results were found by Oliveira et al. (2009) with plants of host carnaúba (Copernicia hospita Martius-Arecaceae) and Santos et al. (2013) with mulungu (Erythrina velutina - Faboideae), where the plants submitted to $50 \%$ shading showed lower stem diameter than those kept in full sunlight.

This variable is very important in the evaluation of the survival potential and growth after planting of forestry plants, whereas plants with larger diameter show greater capacity of formation and growth of new roots, resulting in better survival ability (SOUZA et al., 2006).

Although the larger diameter is a suitable parameter to choose the plants, the treatment at full sunlight is not recommended, because leaf burn and high mortality were observed in the nursery, situation that was not observed in the other treatments.

Plants of E. oleracea conducted in full sunlight showed smaller diameters than those planted in the shade during the first year. However, as the age increased this relationship reversed and the plants at full sunlight had greater diameters than those planted in the shade. This reinforces the importance of low light exposure during the early establishment of the açaizeiro (BOVI, 2004).

Observations made by Sousa (2006) indicate that water availability in the soil and light intensity incident in açai plants under capoeira forest provided photosynthetic conditions favorable to them, justifying the ascendant growth of the diameter and length of the caulicle. However, during the period of lower precipitation and high temperatures the average diameter was reduced while the growth of the caulicle remained constant.

As in the experiment performed in the nursery the water availability was approximately equal and constant for all treatments, the growth of the diameter was directly correlated with luminosity, and the excess of this also caused a reduction of leaf area and atrophy of the plants.

For total dry matter, i.e., the sum of root and aerial part, the greater dry matter was observed with 35\% shading (Figure 5). The total dry matter is the most important variable to be analyze when selecting the level of shading most suitable for plant development, since the greater length of the plantlets is not an indicative of a good plant, but it may reveal the occurrence of etiolation, as it can be observed in Figures 4 and 5, emphasizing that the greater lengths of the aerial part are correlated with the smallest diameters.

In plants of juçara palm grown at $2 \%, 6 \%$, and $20 \%$ of light, the dry matter of root and aerial part, leaf area, number of leaves, and biomass distribution tend to be greater the greater the luminosity the plants grew (NAKAZONO et al., 2001). Plants transferred from low (4\%) to high $(20 \%$ or $30 \%)$ light availability responded to the increase of irradiance, increasing the dry matter of root and aerial part, leaf area, number of leaves, and biomass distribution for the roots. These results are similar to those found in the present study, which showed the best results when the plants were exposed from $35 \%$ to $50 \%$ shading.

The exposure of young plants to full sunlight can cause the reduction of leaf water potential, due to high evaporative demand caused by high radiation, being responsible for increasing its temperature and stomatal restriction to transpiration, that eventually enhances the effects of photoinhibition, and therefore, low biomass production (ARAÚJO; DEMINICIS, 2009). The data of low performance of açai plantlets as affected by high radiation agree with the report of these authors, which affirm that among the abiotic factors that limit the yield of plants, the solar radiation stands out. The increase of light beyond the photosynthetic capacity of the plants can result in a light stress situation known as photoinhibition or solarization, and also can increase respiratory rate, a condition that reduces photosynthetic efficiency, and consequently, mass incorporation by the plants (DIAS; MARENCO, 2007).

In an environment with low luminosity the açaizeiro shows good development and the 
physiological and morphological responses will depend on the levels of radiation they are exposed (GAMA et al., 2003). Conforto and Contin (2009) confirmed these observations when they found that E. oleracea had a better development with $50 \%$ of shading compared to full sunlight. These authors observed an improvement of leaf area expansion, which maximized the interception of clarity and light use more efficiently, leading to increase in carbon gain in low solar irradiations. Light intensity has also direct influence in palm trees survival, as mentioned by Tonetti and Negrelle (2001), which recorded $60 \%$ of mortality in natural environment due to high luminosity.

The ability to grow fast when moderately shaded is an important adaptation mechanism of the species, thus becoming an escape strategy for both low and high luminous intensity. The adaptation to low luminosity is a genetic trait that makes the leaves have anatomical structure and physiological properties that enable them to effectively use the available solar radiation (LARCHER, 2000).

The reduction of height growth in full sunlight is associated with the elevation of leaf temperature, and consequently, the intensification of respiratory rate, which would induce stomatal closure reducing carbon fixation and increasing the consumption of photoassimilates (DIAS; MARENCO, 2007). It should also be emphasized that the shading nets are capable of modifying not only the solar radiation incident, but also temperature, evapotranspiration, relative humidity, besides other meteorological factors, creating a suitable micro climate to plant development.

The plants of açai allocate its energy and biomass production in the medium shading gradations. The production of total dry matter allows the evaluation of the plant growth, and the total amount of accumulated dry matter by the plant is a direct result of net photosynthetic production, plus the amount of mineral nutrients absorbed.

For the production of açaizeiro in the nursery, Oliveira et al. (2002) recommend the use of $50 \%$ shading, which does not agree with the best treatment to those produced in Rio Branco, AC. However, the climatic characteristics of each region, as well as the genotypes used, should be considered.

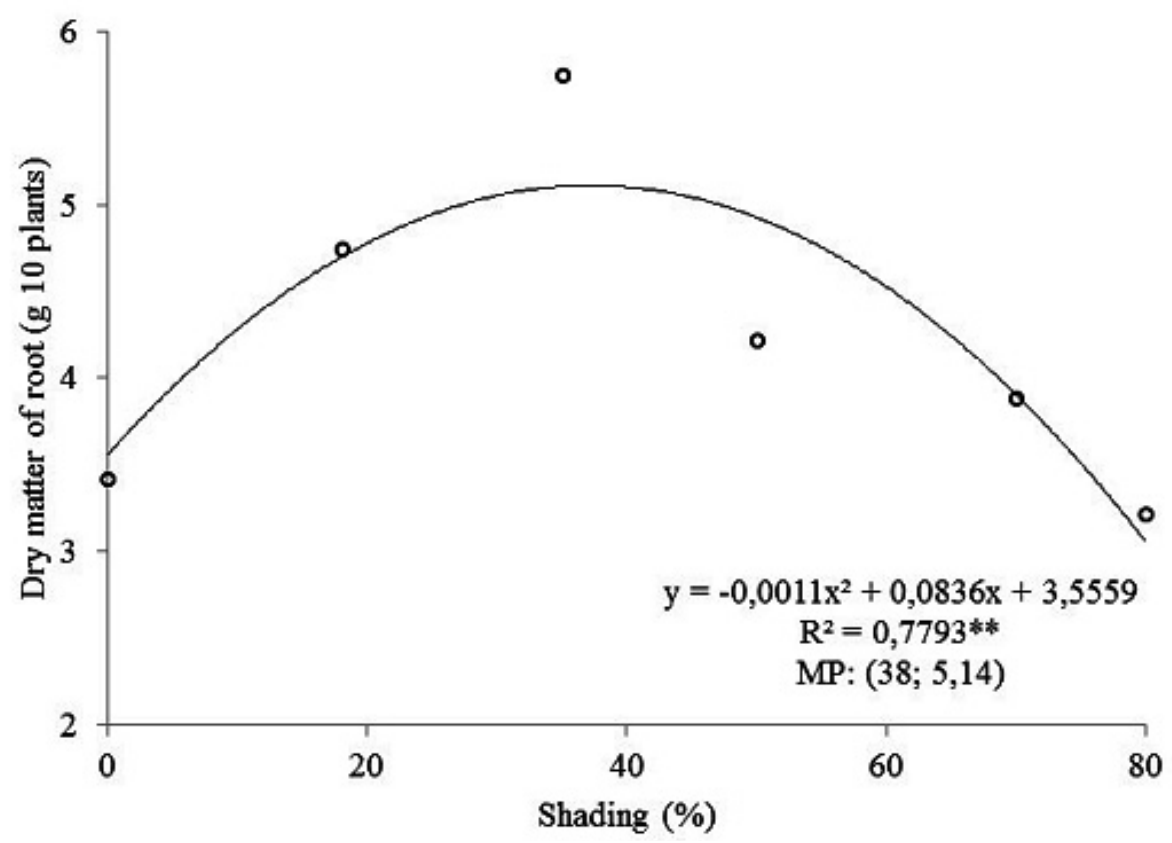

FIGURE 1 - Dry matter of root (g) of açai plants as affected by shading. 


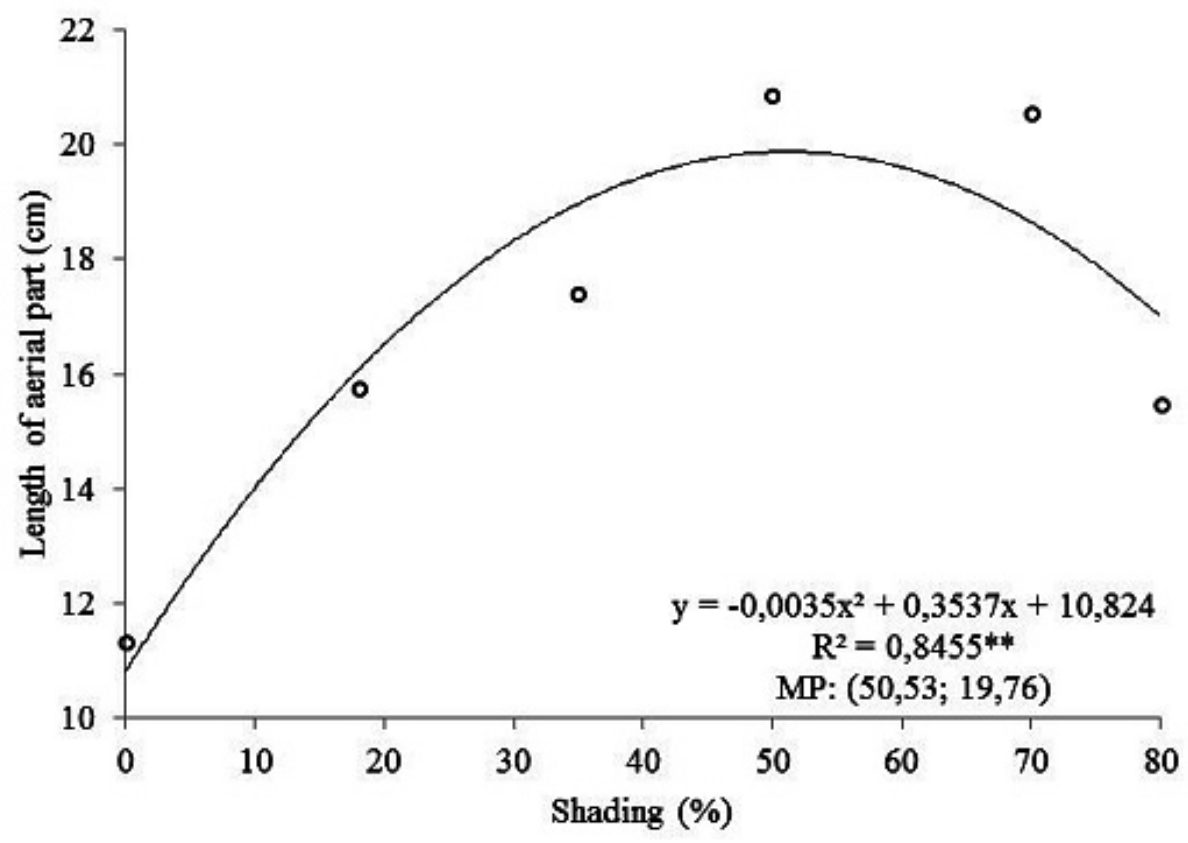

FIGURE 2 - Length (cm) of aerial part of açai plants as affected by shading.

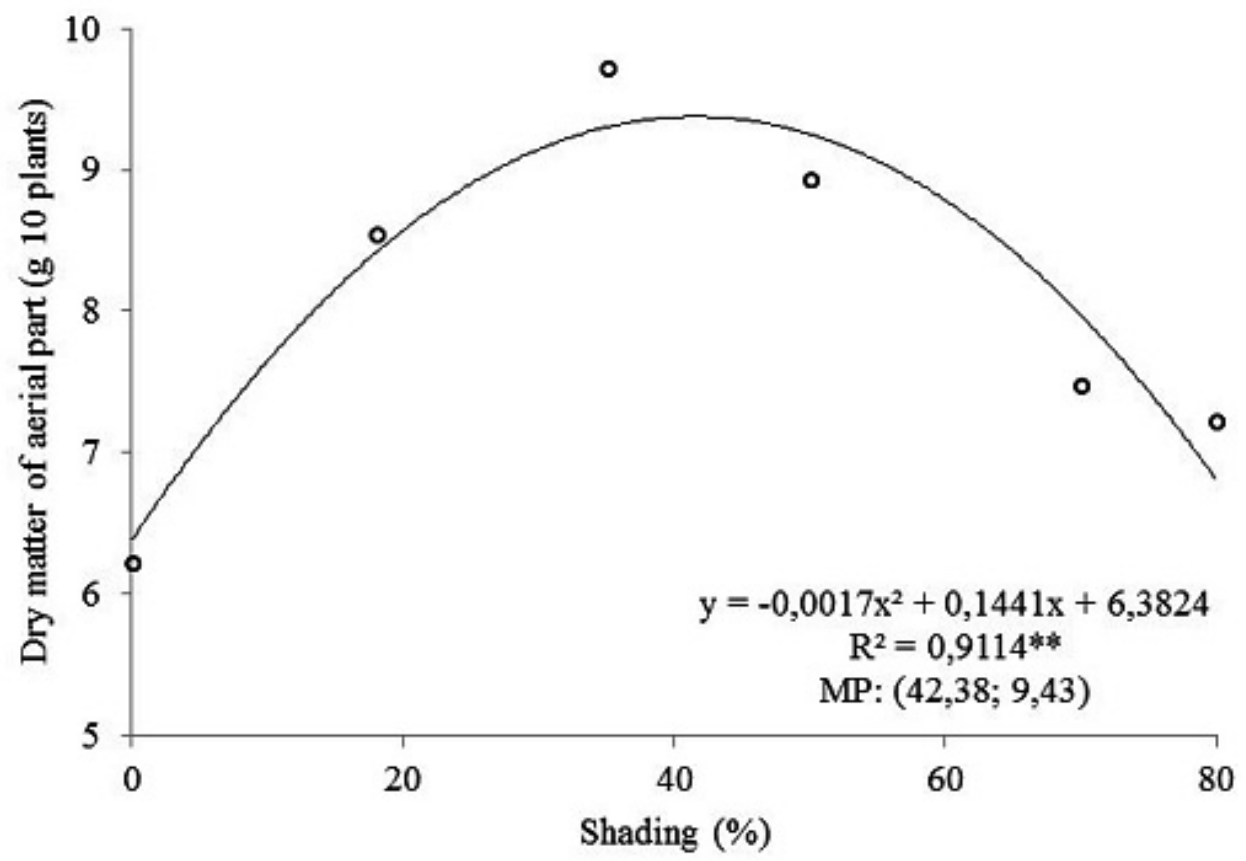

FIGURE 3 - Dry matter of aerial part (g) of açai plants as affected by shading. 


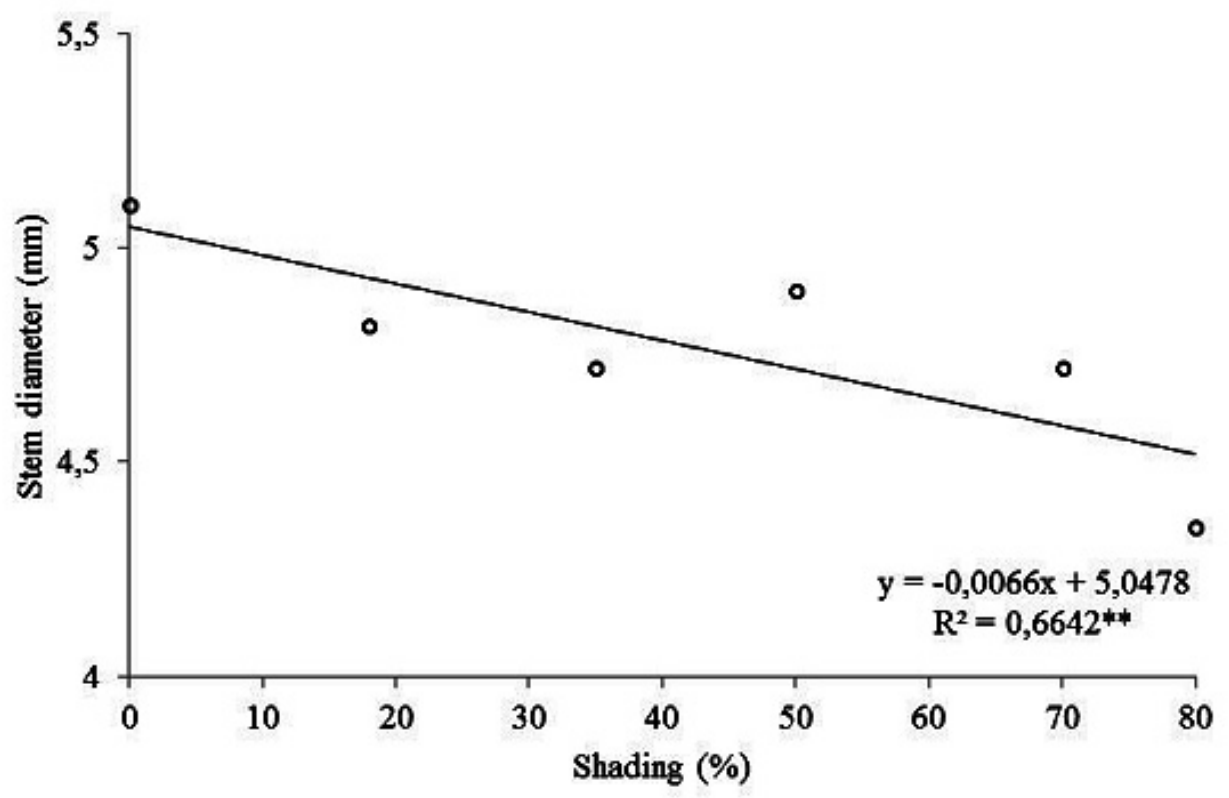

FIGURE 4 - Stem diameter (mm) of açai plants as affected by shading.

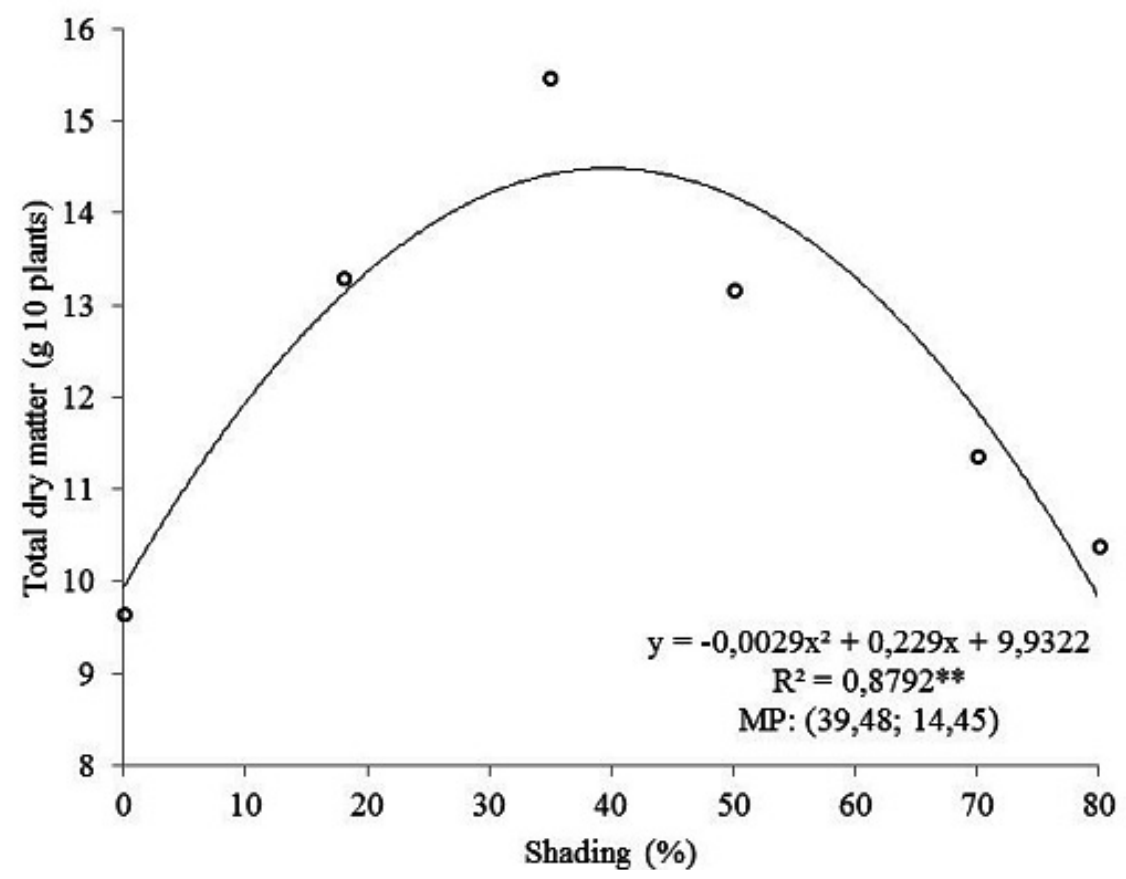

FIGURE 5 - Total dry matter (g) of açai plants as affected by shading. 


\section{CONCLUSION}

Considering the conditions of the experiment, it is concluded that $40 \%$ shading promotes the initial development of açai plants.

\section{REFERENCES}

AGUIAR, C.J.S. Contribuição para a implantação do açaizeiro (Euterpe oleracea Mart.) no litoral paulista. In: ENCONTRO NACIONAL DE PESQUISADORES DE PALMITO, 1988, Curitiba. Anais... Curitiba: Embrapa/CNPF, 1988. p.75-90.

ANTUNES, C.G.C.; SOUZA, C.L.M.; GOMES, H.L.R.; SOUZA, J.V.; BARROSO, N.S.; CASTRO, R.D.; PELACANI, C.R. Desenvolvimento de mudas de catingueira em diferentes substratos e níveis de luminosidade. Cerne, Lavras, v.20, n.1, p.55-60, 2014.

ARAÚJO, S.A.C.; DEMINICIS, B.B. Fotoinibição da fotossíntese. Revista Brasileira de Biociências, Porto Alegre, v.7, n.4, p.463-472, 2009.

BOVI, M.L.A.; TREDUS, P.F.A.; SPIERING, S.H.; BARBOSA, A.M.M.; PIZZINATTO, M.A. Nursery growth of Euterpe oleracea as a function of substrate and container. Acta Horticulturae, Leuven, v.360, p.195-209, 1994.

BOVI, M.L.A. Resultados de pesquisas referentes a exploração, manejo e cultivo do açaizeiro. In: JARDIM, M.A.G.; MOURÃO, L.; GROSSMANN, M. Açaí (Euterpe oleracea Mart.): possibilidades e limites para o desenvolvimento sustentável no estuário amazônico. Belém: Museu Paraense Emílio Goeldi, 2004. p.53-78.

CONFORTO, E.C.; CONTIN, D.R. Desenvolvimento do açaizeiro de terra firme, cultivar Pará, sob atenuação da radiação solar em fase de viveiro. Bragantia, Campinas, v.68, n.4, p.979-983, 2009.

DIAS, D.P.; MARENCO, R.A. Fotossíntese e fotoinibição em mogno e acariquara em função da luminosidade e temperatura foliar. Pesquisa Agropecuária Brasileira, Brasília, v.42, n.3, p.305311, 2007.
FARIA, W.S.; GAIVA, H.N.; PEREIRA, W.E. Comportamento de cinco genótipos de coqueiro (Cocos nucifera L.) na fase de germinação e de crescimento de mudas, sob diferentes sistemas de produção. Revista Brasileira de Fruticultura, Jaboticabal, v.24, n.2, p.458-462, 2002.

FREITAS, G.A.; VAZ-DE-MELO, A.; PEREIRA, M.A.B.; ANDRADE, C.A.O.; LUCENA, G.N.; SILVA, R.R. Influência do sombreamento na qualidade de mudas de Sclerolobium paniculatum Vogel para recuperação de área degradada. Journal of Biotechnology and Biodiversity, Gurupi, v.3, n.3, p.5-12, 2012.

GAMA, J.R.V.; BOTELHO, S.A.; BENTES-GAMA, M.M.; SCOLFORO, J.R.S. Estrutura e potencial futuro de utilização da regeneração natural de floresta de várzea alta no município de Afuá, Estado do Pará. Ciência Florestal, Santa Maria, v.13, n.2, p.71-82, 2003.

GONDIN, J.C.; SILVA, J.B.; ALVES, C.Z.; DUTRA, A.S.; ELIAS JUNIOR, L.Emergência de plântulas de Schizolobium amazonicum Huber ex Ducke (CAESALPINACEAE) em diferentes substratos e sombreamento. Revista Ciência Agronômica, Fortaleza, v.46, n.2, p.329-338, 2015.

ILLENSEER, R.; PAULILO, M.T.S. Crescimento e eficiência de utilização em plantas jovens de Euterpe edulis Mart. sob dois níveis de irradiância, nitrogênio e fósforo. Acta Botânica Brasilica, Belo Horizonte, v.16, n.4, p.385-394, 2002.

LARCHER, W. Ecofisiologia vegetal. São Carlos: RiMa Artes e Textos, 2000. 531 p.

MATOS, G.D.; FRIGOTTO, T.; MARTINS, A.P.M.; BRUN, J.B. Desenvolvimento de mudas de paricá (Schizolobium amazonicum Huber ex Ducke) em substrato orgânico: estudo de caso. Synergismus Scyentifica UFTPR, Pato Branco, v.4, n.1, 2009.

MORELLI, G.; RUBERTI, I. Shade avoidance responses. Driving auxin along lateral routes. Plant Physiology, Rockville, v.122, p.621-626, 2000. 
NAKAZONO, E.M.; COSTA, M.C.; FUTATSUG, K.; PAULILO, M.T.S. Crescimento inicial de Euterpe edulis Mart. em diferentes regimes de luz. Revista Brasileira de Botânica, São Paulo, v.24, n.2, p.173-179, 2001.

OLIVEIRA, A.B.; MEDEIROS FILHO, S.; BEZERRA, A.M.E. Efeito do tamanho da semente, subtrato ambiente na produção de mudas de Copernicia hospita Martius. Ciência e Agrotecnica, Lavras, v.33, n.6, p.1527-1533, 2009.

OLIVEIRA, M.S.P.; CARVALHO, J.E.U.; NASCIMENTO, W.M.O.; MÜLLER, C.H. Cultivo do açaizeiro para produção de fruto. Belém: Embrapa Amazônia Oriental, 2002. 18 p. (Circular Técnica, 26).

REIS, R.G.E.; PEREIRA, M.S.; GONÇALVES, N.R.; PEREIRA, D.S.; BEZERRA, A.M.E. Emergência e qualidade de mudas de Copernicia prunifera em função da embebição das sementes e sombreamento. Revista Caatinga, Mossoró, v.24, n.4, p.43-49, 2011.

RIBEIRO, T.M.; MARTINS, S.V.; LANA, V.M.; SILVA, K.A. Sobrevivência e crescimento inicial de plântulas de Euterpe edulis Mart. transplantadas para clareiras e sub-bosque em uma Floresta Estacional Semidecidual, em Viçosa, MG. Revista Árvore, Viçosa, MG, v.35, n.6, p.1219-1226, 2011.

SANTOS, L.W.; COELHO, M.F.B. Sombreamento e substratos na produção de mudas de Erythrina velutina Willd. Ciência Florestal, Santa Maria, v.23, n.4, p.571-577, 2013.
SCARIOT, A. Weedy and secondary palm species in Central Amazonian forest fragments. Acta Botânica Brasílica, Brasília, v.15, n.2, p.271-280, 2001.

SIEBENEICHLEN, S.C.; FREITAS, A.G.; SILVA, R.R.; ADORIAN, G.C.; CAPELLARI, D. Características morfofisiológicas em plantas de Tabebuia heptaphyilla (Vell,) Tol. em condições de luminosidade. Acta Amazonica, Manaus, v.38, n.3, p.467-472, 2008.

SOUSA, L.A.S. Desenvolvimento de plantas jovens de açaizeiro (Euterpe oleracea Mart.) plantadas em área com vegetação secundária (capoeira) na localidade de Benjamin Constant, município de Bragança, estado do Pará. 2006. 62 f. Dissertação (Mestrado em Botânica Tropical) - Universidade Federal Rural da Amazônia, Manaus, 2006.

SOUZA, C.A.M.; OLIVEIRA, R.B.; MARTINS FILHO, S.; LIMA, J.S.S. Crescimento em campo de espécies florestais em diferentes condições de adubação. Ciência Florestal, Santa Maria, v.16, n.3, p.243-249, 2006.

TONETTI, E.L.; NEGRELLE, R.R.B. Dinâmica de banco de sementes de plântulas de palmiteiro em ambiente natural. Scientia Agrária, Curitiba, v.2, n.1, p.1-7, 2001. 